\title{
Non-operative management of civilian abdominal gunshot wounds
}

\author{
다 Adnan Özpek, M.D., (ㄷ) Tolga Canbak, M.D.
}

Department of General Surgery, University of Health Sciences, Ümraniye Training and Research Hospital, İstanbul-Turkey

\begin{abstract}
BACKGROUND: In this study, we aimed to evaluate the results of selective non-operative management in patients with civilian abdominal gunshot wounds.

METHODS: Patients hospitalized and monitored in our clinic due to civilian abdominal gunshot wounds between January 2009 and January 2018 were retrospectively examined. Patients were studied concerning age, gender, mechanism of injury, anatomic injury site, Penetrating Abdominal Trauma Index (PATI), Injury Severity Score (ISS), Revised Trauma Score (RTS), treatment method, time to operation, days of hospitalization and mortality.

RESULTS: Of the patients, 84 (89.4\%) were male, and 10 (10.6\%) were female with a mean age of 32.7 (range 4-60). The mean ISS, RTS and PATI values of all patients were 17.05, 7.27 and 9.21, respectively. Immediate laparotomy and/or thoracotomy were performed in 21 (22.3\%) of the patients due to hemodynamic instability and in 27 (28.7\%) of the patients because of peritonitis findings. The remaining 46 (48.9\%) patients were managed non-operatively. Among these patients, early laparotomy was performed in five $\mathbf{( 5 . 3 \% )}$ and late laparotomy in eight $(\mathbf{8 . 5 \% )}$ patients who developed peritonitis symptoms. The other $33(35.1 \%)$ patients were treated non-operatively. Of these patients, $61.1 \%$ of the patients with flank injuries, $50 \%$ of the patients with right thoracoabdominal injuries, $44.4 \%$ of the patients with posterior abdominal injuries, $42.1 \%$ of the patients with pelvic injuries and $27.8 \%$ of the patients with left thoracoabdominal injuries were successfully treated non-operatively. Non-therapeutic or negative laparotomy was performed on six (6.4\%) patients. Mortality was $10.6 \%(n=10)$ in all patients.
\end{abstract}

CONCLUSION: Some patients with a civilian abdominal gunshot wound in certain anatomical localization who are hemodynamically stable and have no peritonitis symptoms can be non-operatively managed just as in patients with abdominal stab wounds. Success rates of selective non-operative management are high, especially in gunshot wounds of flank, posterior abdominal, thoracoabdominal and pelvic regions.

Keywords: Abdominal trauma; civilian; gunshot wound; selective non-operative management.

\section{INTRODUCTION}

While mandatory explorative laparotomy has been performed in penetrating abdominal traumas in the first half of the $20^{\text {th }}$ century, selective non-operative management (SNOM) became a current issue and was introduced especially in abdominal stab wounds (ASW) after a study published by Shaftan in 1960. Later, in 1974, Nance et al. reported that SNOM is a safe and effective method in abdominal gunshot wounds (AGSW). ${ }^{[1]}$
In the following years, SNOM has been recognized in ASW by surgeons worldwide and is still commonly applied today. However, surgeons' hesitation in practice still continues about SNOM for AGSW in our country and in many countries of the world. In several surveys conducted among surgeons in our country and other countries around the world, at least half of surgeons did not find SNOM as a safe and effective method in AGSW. ${ }^{[2-4]}$

Cite this article as: Özpek A, Canbak T. Non-operative management of civilian abdominal gunshot wounds. Ulus Travma Acil Cerrahi Derg 2020;26:227-234

Address for correspondence: Adnan Özpek, M.D.

Sağlık Bilimleri Üniversitesi, Ümraniye Eğitim ve Araştırma Hastanesi, Genel Cerrahi Kliniği, İstanbul, Turkey

Tel: +90 216 - 6321818 E-mail: adnanozpek@mynet.com

Ulus Travma Acil Cerrahi Derg 2020;26(2):227-234 DOI: 10.14744/tjtes.2020.86I32 Submitted: 01.07.2019 Accepted: 06.01.2020 Online: 24.02.2020

Copyright 2020 Turkish Association of Trauma and Emergency Surgery 
In this study, we aimed to investigate the safety and effectiveness of SNOM in patients with AGSW who were treated in our clinic.

\section{MATERIALS AND METHODS}

This clinical study was approved by the Health Sciences University, Umraniye Training and Research Hospital Clinical Research Ethics Committee (Reference Number: 2019/23526665). Written informed consent was obtained from all patients.

Patients hospitalized and monitored in our clinic due to civilian AGSW between January 2009 and January 2018 were retrospectively examined from the prospective database. Patients were studied regarding age, gender, mechanism of injury, anatomic injury site, Penetrating Abdominal Trauma Index (PATI), Injury Severity Score (ISS), Revised Trauma Score (RTS), treatment method, time to operation, days of hospitalization and mortality. Resuscitation was performed in the emergency room in accordance with the Advanced Trauma Life Support (ATLS) guidelines.

Patients who were hemodynamically unstable or with peritonitis symptoms were immediately taken to operation wheras patients who were hemodynamically stable and without peritonitis symptoms underwent double or triple contrast CT.

Patients with no evidence of hollow viscus injury on $\mathrm{CT}$ were hospitalized and monitored in our clinic. These patients were followed-up with intermittent physical examination and laboratory testing as much as possible by the same team. Among these, patients who developed peritonitis symptoms or with unsustainable hemodynamic stability were operated. In addition, rectosigmoidoscopy or colonoscopy was performed in patients when necessary depending on anatomic localization and/or clinical findings. Appropriate surgical procedures were performed in patients with rectum or colon wounds detected by endoscopy. The remaining patients were non-operatively treated.

\section{Statistical Analysis}

The Statistical Package for the Social Sciences statistical software package (version 21.0 SPSS Inc, Chicago, Illinois) was used. Variables were expressed as mean \pm standard deviation (SD) or median (range), depending on their distribution. Categorical variables were expressed as frequencies and percentages. Chi-square test was used for comparison of continuous parametric variables. The differences were considered statistically significant if the $\mathrm{p}$-value was less than 0.05 .

\section{Anatomic Localization}

Posterior abdomen: Bilaterally, superiorly posterior subcostal margins, laterally posterior axilla lines, inferiorly hip folds.

Flank: Bilaterally, superiorly arcus costarum margins, ante- riorly anterior axilla lines, posteriorly posterior axilla lines, inferiorly upper margins of the iliac spine.

Pelvic region: Superiorly a horizontally line crossing spina iliaca anterior superiors, inferiorly perine region.

\section{Operation Time}

Immediate laparotomy: Laparotomy performed within two hours of the patient's admission to the emergency room.

Early laparotomy: Laparotomy performed between 2-8 hours of admission.

Late laparotomy: Laparotomy performed eight hours after admission.

\section{RESULTS}

Among a total of patients with GSW hospitalized and treated in our clinic during the study period, 94 patients with civilian AGSW were included in this study. Among these patients, there was not any patient injured with military guns. Of the patients, $84(89.4 \%)$ were male, 10 (10.6\%) female and the mean age was $32.7 \pm 10.3$ (range 4-60). Eighty-two (87.2\%) patients were injured with bullet and 12 (I2.8\%) with buckshot.

Immediate laparotomy and/or thoracotomy were performed in 21 (22.3\%) patients due to hemodynamic instability and in $27(28.7 \%)$ patients because of peritonitis findings. The other $46(48.9 \%)$ patients underwent double or triple contrast CT examination, hospitalized and monitored in our clinic and managed with SNOM. Among these patients, early laparotomy was performed in five $(5.3 \%)$ patients and late laparotomy in eight (8.5\%) patients who developed peritonitis symptoms. The other 33 (35.1\%) patients were non-operatively treated. Statistically, the rate of successful SNOM was significantly higher in patients with buckshot injuries than patients with bullet injuries $(p=0.028)$ (Table I).

Of the patients who underwent immediate operation due to hemodynamic instability; 13 underwent laparotomy, six patients underwent thoracotomy and two patients underwent laparotomy plus thoracotomy. All other operated patients underwent laparotomy. Tube thoracostomy was inserted in I3 (I3.8\%) patients.

Non-therapeutic or negative laparotomy was performed on six $(6.4 \%)$ patients. Of these patients, two patients were operated immediately due to hemodynamic instability, two patients were operated immediately because of peritonitis symptoms, one patient underwent early laparotomy and one patient underwent late laparotomy with peritonitis symptoms (Table I).

The mean ISS, RTS and PATI values of all patients were calculated as $17.05 \pm 1.29,7.27 \pm 0.15$ and $9.21 \pm 1.19$, respectively. In 
Table I. Distribution of patients according to the mechanism of injury and treatment

\begin{tabular}{|c|c|c|c|c|}
\hline & $\begin{array}{c}\text { Bullet } \\
(n=82)\end{array}$ & $\begin{array}{c}\text { Buckshot } \\
(n=12)\end{array}$ & $\begin{array}{l}\text { Total } \\
(n=94)\end{array}$ & $\mathbf{p}^{*}$ \\
\hline Immediate laparatomy (Hemodynamic instability) & 20 & I & 21 & $0.0134^{* *}$ \\
\hline Immediate laparatomy (Peritonitis) & 26 & 1 & 27 & \\
\hline Early laparotomy & 5 & - & 5 & 0.3793 \\
\hline Late laparatomy & 5 & 3 & 8 & $0.0284^{* *}$ \\
\hline Negative laparatomy & 5 & 1 & 6 & 0.5699 \\
\hline Successful SNOM & 26 & 7 & 33 & $0.0206^{* *}$ \\
\hline
\end{tabular}

${ }^{*}$ Chi-square test; ${ }^{* *}$ Statistically significant $(p<0.05)$.

Table 2. Mean ISS, PATI and RTS values of operated and SNOM patients

\begin{tabular}{lccc}
\hline & Operated & SNOM & $\mathbf{p}^{*}$ \\
\hline ISS & $21.90 \pm 1.63$ & $8.09 \pm 0.84$ & $<0.0001^{* *}$ \\
PATI & $13.72 \pm 1.56$ & $0.88 \pm 0.34$ & $<0.0001^{* *}$ \\
RTS & $6.29 \pm 0.20$ & $7.84 \pm 0.0$ & $0.0119^{* *}$ \\
\hline
\end{tabular}

ISS: Injury Severity Score; PATI: Penetrating Abdominal Trauma Index; RTS: Revised Trauma Score; SNOM: Selective non-operative management. *Chi-square test; **Statistically significant $(p<0.05)$.

operated patients, these values were $21.90 \pm 1.63,6.30 \pm 0.20$, $13.72 \pm 1.55$, respectively. In patients who was treated with SNOM, values were $8.09 \pm 0.84,7.84 \pm 0.0,0.88 \pm 0.34$, respectively. There was a statistically significant difference between the operated and non-operated patients in all scores $(p<0.0001, p<0.0001, p=0.0119$, respectively) (Table 2).

A total of 112 differrent anatomical site injuries were determined in this study. Twenty-eight of these injuries were anterior abdominal, nine posterior abdominal, 20 right thoracoabdominal, 18 left thoracoabdominal, 18 flank and 19 were pelvic. Of these patients, $61.1 \%$ of the patients with flank injuries, $50 \%$ of the patients with right thoracoabdominal injuries, $44.4 \%$ of the patients with posterior abdominal injuries, $42.1 \%$ of the patients with pelvic injuries and $27.8 \%$ of the patients with left thoracoabdominal injuries were successfully treated with SNOM, whereas SNOM could be successfully performed only in one $(3.4 \%)$ of the patients with anterior abdominal region wound (Figs. Ia, b and 2a-d). Although there was no statistically significant difference in other anatomical site injuries, the rate of successful SNOM in flank injuries was statistically significant higher than the others $(p=0.031)$ (Table 3$)$.

Liver, spleen, heart, intraabdominal or iliac large vessel injuries and massive haemothorax were the most common causes in patients who were operated immediately with haemodynamic instability. In patients who were operated with signs of peritonitis, small intestine, colon and stomach injuries were the main causes. There were three Grade II liver injury, one Grade III spleen injury and one Grade I kidney injury in CT images of patients treated with SNOM (Table 4).
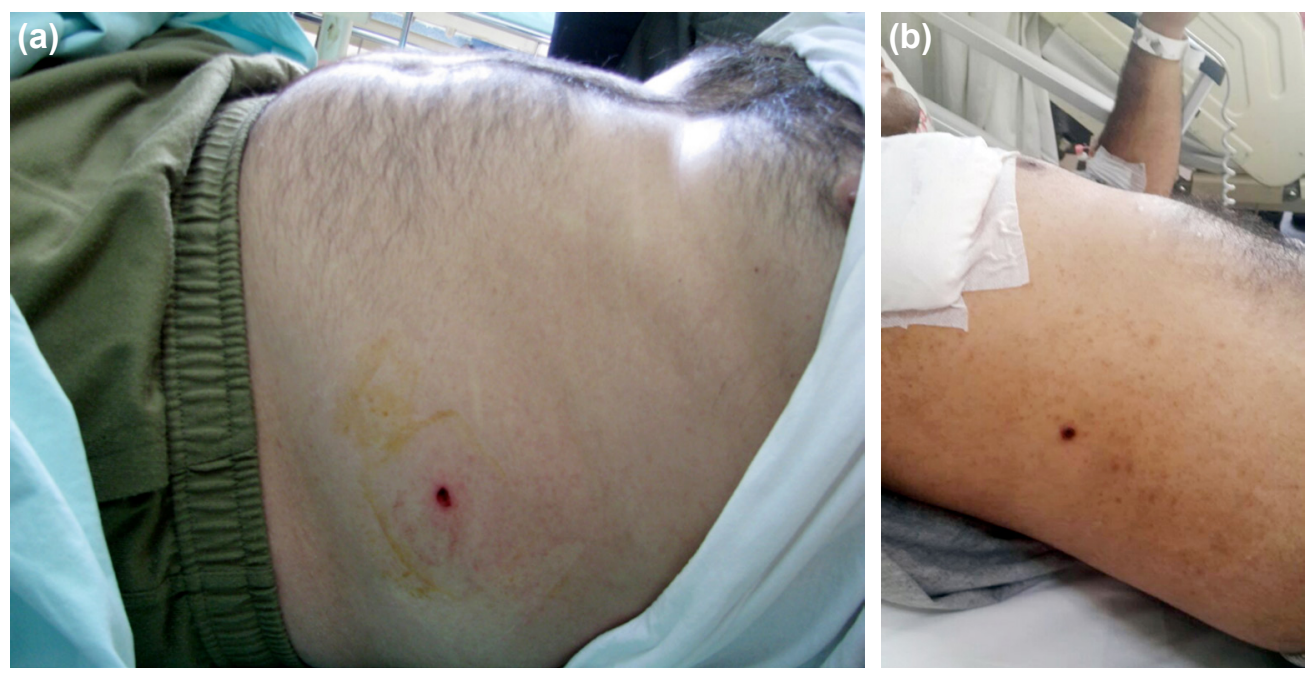

Figure 1. (a) Patient with a bullet injury localized in left flank successfully treated with SNOM. (b) Patient with right thoracoabdominal bullet injury successfully treated with SNOM. 

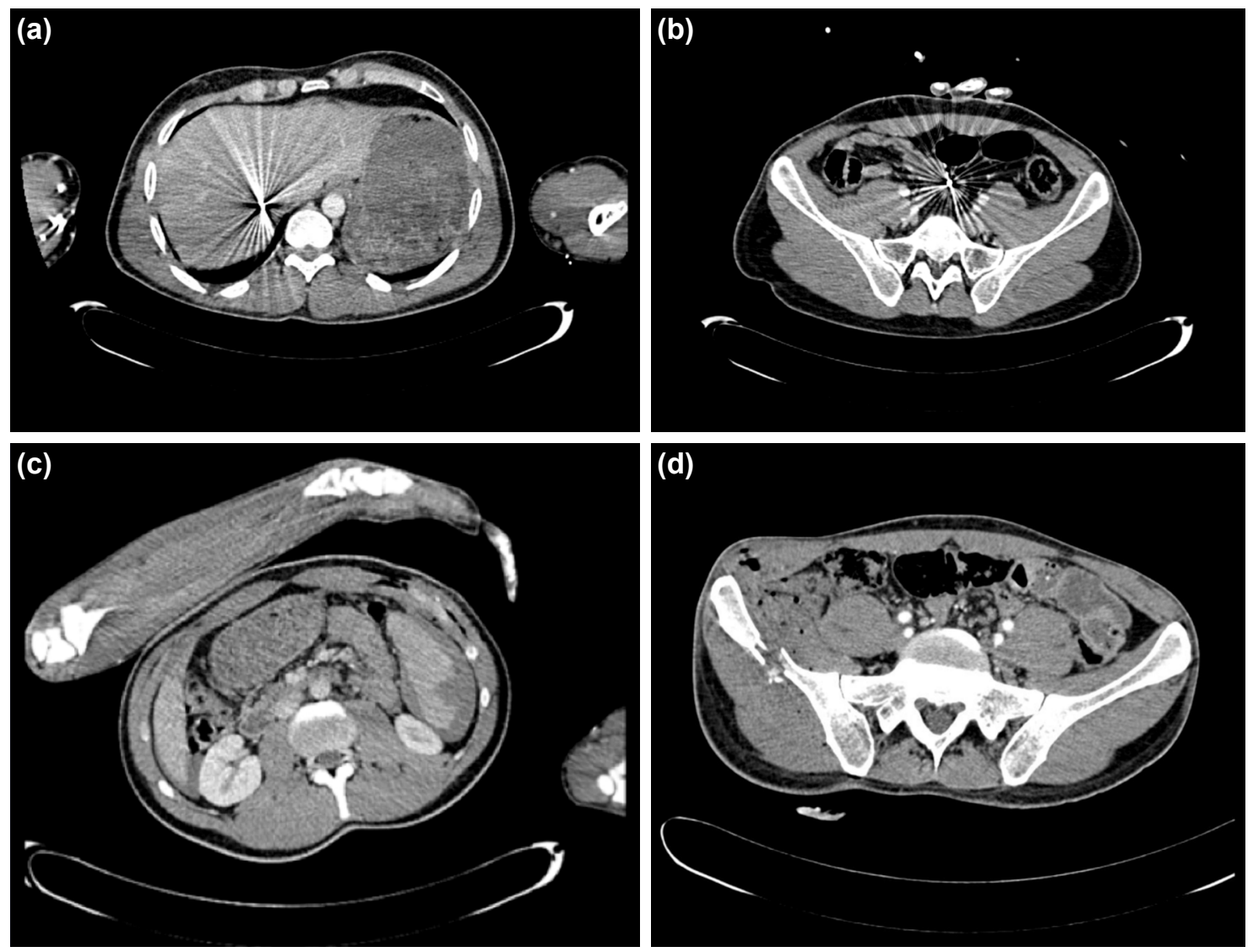

Figure 2. (a) CT image of a patient with right thoracoabdominal buckshot injury successfully treated with SNOM. (b) CT image of a patient with pelvic buckshot injury successfully treated with SNOM. (c) CT image of a patient with left thoracoabdominal GSW and grade III spleen injury successfully treated with SNOM. (d) CT image of a patient with pelvic bullet injury and iliac fracture successfully treated with SNOM.

The mean duration of hospitalization was found as $9.96 \pm 6.55$ (range 4-22) days in patients operated, 3.4I \pm 2.67 (range I-II) days in patients with successful SNOM, 7.40 \pm 2.70 (range 4-II) days in patients underwent early laparotomy, $11.14 \pm 7.31$ (range 5-27) days in patients underwent late laparotomy and 7.16 \pm 4.70 (range 4-19) days in patients underwent non-therapeutic or negative laparotomy. Average number of hospitalization days was statistically significant lower in patients who were successfully treated with SNOM than operated patients $(p=0.031)$ (Table 5).

A total of 10 patients $(10.6 \%)$ resulted in mortality. Of these, nine patients were operated immediately due to hemodynamic instability, and one patient underwent SNOM and had external iliac and femoral vessel injury that accompanying pelvic region wound.

Table 3. Distribution of patients according to anatomical injury sites and treatment modalities

\begin{tabular}{|c|c|c|c|c|c|c|c|}
\hline Injury sites & $\begin{array}{l}\text { Immediate L. } \\
\text { (H.instability) }\end{array}$ & $\begin{array}{l}\text { Immediate L. } \\
\text { (Peritonitis) }\end{array}$ & Early L. & Late $\mathbf{L}$. & Negative L. & $\begin{array}{l}\text { Successful } \\
\text { SNOM (\%) }\end{array}$ & $\mathbf{p}^{*}$ \\
\hline Anterior abdominal $(n=28)$ & 7 & 13 & 4 & 3 & I & I (3.4\%) & 0.070 \\
\hline Posterior abdominal $(n=9)$ & 2 & 3 & - & - & - & $4(44.4 \%)$ & 0.711 \\
\hline Right thoracoabdominal $(n=20)$ & 8 & 2 & - & - & - & $10(50 \%)$ & 0.216 \\
\hline Left thoracoabdominal $(n=\mid 8)$ & 7 & 4 & - & 2 & 1 & $5(27.8 \%)$ & 0.789 \\
\hline Flank $(n=18)$ & 2 & 4 & - & I & 2 & II (6I.1\%) & $0.031^{* *}$ \\
\hline Pelvic $(n=19)$ & 1 & 4 & I & 5 & 3 & $8(42.1 \%)$ & 0.608 \\
\hline Total $(n=|| 2)$ & 27 & 30 & 5 & 11 & 7 & $39(34.8 \%)$ & \\
\hline
\end{tabular}

$\mathrm{H}:$ Hemodynamic; L: Laparatomy; ${ }^{*}$ Chi-square test; $* *$ Statistically significant $(\mathrm{p}<0.05)$. 
Table 4. Organ injuries in all patients underwent surgery and treated with SNOM

\begin{tabular}{|c|c|c|c|c|c|c|}
\hline Injured organ & $\begin{array}{l}\text { Immediate L/T. } \\
\text { (H. instability) }\end{array}$ & $\begin{array}{l}\text { Immediate L. } \\
\text { (Peritonitis) }\end{array}$ & $\begin{array}{c}\text { Early } \\
\text { Laparotomy }\end{array}$ & $\begin{array}{c}\text { Late } \\
\text { Laparotomy }\end{array}$ & SNOM & Total \\
\hline Stomach & 3 & 6 & - & 1 & - & 10 \\
\hline Duodenum & 3 & - & 1 & - & - & 4 \\
\hline Small intestine & 6 & 13 & 3 & 3 & - & 25 \\
\hline Colon & 5 & 8 & 1 & 2 & - & 16 \\
\hline Rectum & I & 1 & - & 1 & - & 3 \\
\hline Liver & 6 & 3 & 2 & - & 3 & 14 \\
\hline Gallbladder & I & - & - & - & - & 1 \\
\hline Pancreas & 2 & 1 & - & - & - & 3 \\
\hline Spleen & 2 & 3 & - & - & 1 & 6 \\
\hline Portal vein & I & - & - & - & - & I \\
\hline V. cava inferior & 7 & 2 & 1 & - & - & 10 \\
\hline Aorta & I & - & - & - & - & I \\
\hline Iliac vessels & 4 & - & - & - & 1 & 5 \\
\hline Massive haemotx. & 4 & - & - & - & - & 4 \\
\hline Diaphragma & 3 & 3 & - & - & - & 6 \\
\hline Heart & 3 & - & - & - & - & 3 \\
\hline Lung & 3 & - & - & - & 6 & 9 \\
\hline Kidney & 2 & 1 & - & - & 1 & 4 \\
\hline Bladder & 2 & 2 & - & - & - & 4 \\
\hline Urethra & - & I & - & - & I & 2 \\
\hline
\end{tabular}

L: Laparatomy; T: Thoracotomy; H: Haemodynamic instability; SNOM: Selective non-operative management.

Table 5. Average number of hospitalization days

\begin{tabular}{|c|c|c|c|c|c|c|}
\hline & Operated patients & SNOM patients & Early L. & Late L. & Negative L. & $\mathbf{p}^{*}$ \\
\hline Duration of hospital stay (mean $\pm S D$ ) & $9.96 \pm 6.55$ & $3.4 I \pm 2.67$ & $7.40 \pm 2.70$ & $|1| 4 \pm 7.3 \mid$. & $7.16 \pm 4.70$ & $0.031^{* *}$ \\
\hline Range (day) & $4-32$ & $1-11$ & $4-11$ & $5-27$ & $4-19$ & \\
\hline
\end{tabular}

SNOM: Selective non-operative management; L: Laparatomy; SD: Standard deviation. "Chi-square test; "*tatistically significant $(p<0.05)$.

Intraabdominal or iliac major vascular injuries, high-grade liver injuries, heart injuries and massive hemothorax were the leading causes of mortality (Table 6).

The mean ISS, RTS and PATI values of died patients were $37.50 \pm 4.38,3.30 \pm 0.63$ and $24.10 \pm 6.26$, respectively. In surviving patients, values were $14.62 \pm 1.08,6.93 \pm 0.03,7.44 \pm 0.96$, respectively. There was a statistically significant difference for all scores between patients who died and survivors ( $\mathrm{p}<0.000 \mathrm{I}, \mathrm{p}<0.000 \mathrm{I}, \mathrm{p}<0.000 \mathrm{I}$, respectively) (Table 7).

\section{DISCUSSION}

There are different reasons why SNOM is not widely accepted among surgeons in ASGW. In a study published by Velmahos et al. that gathered the reasons of this hesitate un- der three titles: First, belief of that the incidence of intraabdominal injury is higher than $90 \%$ in AGSWs; second, thought of that explorative laparotomy does not harm the patient and third, belief of that clinical examination is not safe in followup of these patients whereas, the same study conducted with I,856 patients showed that these dogmas were not true and $38 \%$ of patients were successfully treated non-operatively. ${ }^{[5]}$ Similarly, in our present study, we found the rate of succesful SNOM to be $34.8 \%$.

The goal of SNOM in penetrating abdominal traumas is to reduce unnecessary laparotomies and associated complications and to shorten the duration of hospitalization. ${ }^{[2,5]}$ Studies have shown that unnecessary laparotomy leads to various complications up to $41 \%$ and extend the duration of hos- 
Table 6. Organ injuries of the died patients

\begin{tabular}{ll}
\hline Injured organ & Number of the patients \\
\hline V.cava inferior & 6 \\
Iliac vessels & 3 \\
Liver & 3 \\
Heart & 2 \\
Massive haemothorax & 2 \\
Diaphragma & 2 \\
Aorta & 1 \\
Stomach & 2 \\
Duodenum & 2 \\
Pancreas & 2 \\
Small intestine & 3 \\
Colon & 2 \\
Rectum & 1 \\
Kidney & 2 \\
Urethra & 1 \\
\hline
\end{tabular}

Table 7. Mean ISS, PATI and RTS values of survivor and died patients

\begin{tabular}{lccc}
\hline & Survivors & Non-survivors & $\mathbf{p}^{*}$ \\
\hline ISS & $\mid 4.62 \pm 1.08$ & $37.50 \pm 4.38$ & $<0.000 I^{* *}$ \\
PATI & $7.44 \pm 0.96$ & $24.10 \pm 6.26$ & $<0.000 I^{* *}$ \\
RTS & $6.93 \pm 0.03$ & $3.30 \pm 0.63$ & $<0.000 I^{* *}$ \\
\hline
\end{tabular}

ISS: Injury Severity Score; PATI: Penetrating Abdominal Trauma Index; RTS: Revised Trauma Score; "Chi-square test; "'Statistically significant $(p<0.05)$.

pitalization in patients with abdominal penetrating traumas. ${ }^{[6-8]}$ In the present study, we found that the duration of hospitalization was shorter in patients who underwent SNOM compared to patients who underwent negative laparotomy $(3.4 I \pm 2.67$ vs. $7.16 \pm 4.70$ days).

SNOM-related studies in patients with AGSW stated that the patient should be hemodynamically stable, should have no peritonitis symptoms, and should be evaluable for clinical examination (no accompanying head trauma and spinal injury, no intoxication due to alcohol or substances, and no need for sedation or intubation). Patients who meet these conditions can be managed with SNOM if there is no evidence of luminal organ injury on contrast-enhanced Computed Tomography (CT). ${ }^{[5,9]}$ These patients should be monitored for at least 1224 hours and should be evaluated with intermittent physical examinations and laboratory tests by as much as possible the same surgical team..$^{[9,10]}$ In our study, all of the patients who underwent SNOM were conscious, and there was no evidence of hollow viscus injury on their computed tomography. We also monitored and observed our patients with intermit- tent physical examinations and laboratory findings for at least 24-48 hours.

Studies reported between $16 \%$ and $50 \%$ successful non-operative treatment rates for all anatomical abdominal regions. ${ }^{[10-15]}$ In the current study, we achieved similar results (35.1\%).

Successful results reaching high rates have been achieved, especially in flank, pelvis, hip and posterior abdominal GSWs that are likely to tangentially cross the peritoneum. Also, in the right and left thoracoabdominal GSWs, hollow viscus injuries occur less frequently even if they are penetrating the peritoneum. In their study, Velmahos et al. ${ }^{[5]}$ reported successful SNOM results by $30 \%$ anterior AGSW and $65 \%$ posterior AGSW. In that study, since the authors included the right, left thoracoabdominal and pelvic regions into the anterior abdominal region, the rate of successful SNOM of the anterior abdominal GSWs is quite high. However, in our study, we found that the rate of successful SNOM in the injuries of the anterior abdominal region was very low (3.4\%). Our results in posterior abdominal injury were more similar in the same study (44.4\%). In another study by Velmahos et al., successful SNOM rates were reported by $40.5 \%$ in pelvic GSW. ${ }^{[16]}$ The results of our study were similar (42.1\%).

DuBose et al. ${ }^{[10]}$ reported that 12 of 13 patients with liver, spleen and kidney injuries due to ASGW treated non-operatively. In their study, Starling et al. ${ }^{[17,18]}$ performed SNOM in 109 patients with Grade I-V liver injury due to the right thoracoabdominal GSW and laparotomy was needed only in four patients. In the same study, the failure rate of SNOM was $7.1 \%$ in 28 patients with Grade I-III kidney injuries. In our study, five of the patients treated with SNOM had solid organ injury on abdominal CT. Three of these had Grade II liver injuries, one had Grade III spleen and one had Grade I kidney injury.

There are also systematic review studies on this issue. In a collective review study, Singh and Hardcastle ${ }^{[19]}$ reviewed 37 studies between 1960 and 2003 and reported their results. In this study, $30.3 \%$ of the 21.300 patients with gunshot wounds were treated nonoperatively with a success rate of $85.2 \%$. In a similar review study, Lamb and Garner ${ }^{[20]}$ found that successful SNOM was performed in $32.2 \%$ of the 18,602 patients in 22 studies between 1990 and 20I2. In that study, mortality was reported as $0.7 \%$ in patients who underwent SNOM and $1.1 \%$ in the non-therapeutic laparotomy group. In these studies, SNOM insufficiency was reported as approximately $15 \%$. Reasons for this were reported as the development of peritonitis signs in $90 \%$ of the patients and unsustainable haemodynamic stability in $10 \% .{ }^{[19,20]}$ In the present study, the rate of SNOM was $48.9 \%$, and the success rate was $71.7 \%$. SNOM deficiency was due to the development of peritonitis findings in all of our patients. Mortality developed in one patient on whom we managed SNOM. However, this patient had a trans-pelvic injury and died from an external iliac artery injury, not an intra-abdominal organ injury. 
In another study by Zafar et al. ${ }^{[21]}$ reported that $22.2 \%$ of the 12,707 patients with AGSW were managed with SNOM between 2002 and 2008. In that study, late laparotomy increased the risk of mortality by approximately 4,5 folds. Conversely, there are publications reporting that late laparotomy does not increase morbidity and mortality in penetrating abdominal traumas. ${ }^{[22,23]}$ In the present study, none of our patients who underwent late laparotomy resulted in mortality.

In general, the results of our study are similar to the abovementioned studies. In our study, we performed SNOM successfully in $35.1 \%$ of selected patients with civilian AGSW and reduced the rate of unnecessary laparotomy to $6.4 \%$.

\section{Limitations}

The limitations of this study included the relatively small number of patients and were not performed prospectively because of the urgency of the patients.

\section{Conclusion}

Rates of unnecessary laparotomies, associated morbidities and hospital stays can be reduced by performing SNOM in selected patients with civilian AGSW. Success rates of SNOM are high, especially in pelvic, thoracoabdominal, flank and posterior abdominal GSWs. However, prospective randomized studies and evidence are needed to reach a definite conclusion on this subject. It should be considered that SNOM can provide successful results in patients with civilian AGSW.

Ethics Committee Approval: Approved by the local ethics committee.

Peer-review: Internally peer-reviewed.

Authorship Contributions: Concept: A.Ö.; Design: A.Ö., T.C.; Supervision: A.Ö., T.C.; Materials: A.Ö., T.C.; Data: A.Ö.; Analysis: A.Ö., T.C.; Literature search: A.Ö.; Writing: A.Ö., T.C.; Critical revision: A.Ö.

Conflict of Interest: None declared.

Financial Disclosure: The autors declared that this study has received no financial support.

\section{REFERENCES}

1. Salim A, Velmahos GC. When to operate on abdominal gunshot wounds. Scand J Surg 2002;91:62-6. [CrossRef]

2. Karateke F, Özyazıcı S, Daş K, Menekșe E, Önel S, Özdoğan M, et al. General approach to penetrating abdominal traumas of Turkish general surgeons: survey of practice. [Article in Turkish]. Ulus Travma Acil Cerrahi Derg 2013;19:463-8. [CrossRef]

3. Jansen JO, Inaba K, Resnick S, Fraga GP, Starling SV, Rizoli SB, et al. Selective non-operative management of abdominal gunshot wounds: survey of practise. Injury 2013;44:639-44. [CrossRef]

4. Jansen JO, Inaba K, Rizoli SB, Boffard KD, Demetriades D. Selective non-operative management of penetrating abdominal injury in Great Britain and Ireland: survey of practice. Injury 2012;43:1799-804. [CrossRef]
5. Velmahos GC, Demetriades D, Toutouzas KG, Sarkisyan G, Chan LS, Ishak R, et al. Selective nonoperative management in 1,856 patients with abdominal gunshot wounds: should routine laparotomy still be the standard of care? Ann Surg 2001;234:395-402; discussion 402-3. [CrossRef]

6. Renz BM, Feliciano DV. Unnecessary laparotomies for trauma: a prospective study of morbidity. J Trauma 1995;38:350-6. [CrossRef]

7. Weigelt JA, Kingman RG. Complications of negative laparotomy for trauma. Am J Surg 1988;156:544-7. [CrossRef]

8. Demetriades D, Vandenbossche P, Ritz M, Goodmann D, Kowalszik J. Non-therapeutic operations for penetrating trauma: early morbidity and mortality. Br J Surg 1993;80:860-1. [CrossRef]

9. Butt MU, Zacharias N, Velmahos GC. Penetrating abdominal injuries: management controversies. Scand J Trauma Resusc Emerg Med 2009;17:19. [CrossRef]

10. DuBose J, Inaba K, Teixeira PG, Pepe A, Dunham MB, McKenney M. Selective non-operative management of solid organ injury following abdominal gunshot wounds. Injury 2007;38:1084-90. [CrossRef]

11. Moore EE, Moore JB, Van Duzer-Moore S, Thompson JS. Mandatory laparotomy for gunshot wounds penetrating the abdomen. Am J Surg 1980;140:847-51. [CrossRef]

12. Laing GL, Skinner DL, Bruce JL, Bekker W, Oosthuizen GV, Clarke DL. A multi faceted quality improvement programme results in improved outcomes for the selective non-operative management of penetrating abdominal trauma in a developing world trauma centre. Injury 2014;45:327-32.

13. Demetriades D, Charalambides D, Lakhoo M, Pantanowitz D. Gunshot wound of the abdomen: role of selective conservative management. $\mathrm{Br} \mathrm{J}$ Surg 1991;78:220-2. [CrossRef]

14. Okuş A, Sevinç B, Ay S, Arslan K, Karahan Ö, Eryılmaz MA. Conservative management of abdominal injuries. Ulus Cerrahi Derg 2013;29:153-7. [CrossRef]

15. Lichte P, Oberbeck R, Binnebösel M, Wildenauer R, Pape HC, Kobbe P. A civilian perspective on ballistic trauma and gunshot injuries. Scand J Trauma Resusc Emerg Med 2010;18:35. [CrossRef]

16. Velmahos GC, Demetriades D, Cornwell EE 3rd. Transpelvic gunshot wounds: routine laparotomy or selective management?. World J Surg 1998;22:1034-8. [CrossRef]

17. Starling SV, de Azevedo CI, Santana AV, Rodrigues Bde L, Drumond DA. Isolated liver gunshot injuries: nonoperative management is feasible?. Rev Col Bras Cir 2015;42:238-43. [CrossRef]

18. Starling SV, Rodrigues Bde L, Martins MP, da Silva MS, Drumond DA. Non operative management of gunshot wounds on the right thoracoabdomen. Rev Col Bras Cir 2012;39:286-94. [CrossRef]

19. Singh N, Hardcastle TC. Selective non operative management of gunshot wounds to the abdomen: a collective review. Int Emerg Nurs 2015;23:22-31. [CrossRef]

20. Lamb CM, Garner JP. Selective non-operative management of civilian gunshot wounds to the abdomen: a systematic review of the evidence. Injury 2014;45:659-66. [CrossRef]

21. Zafar SN, Rushing A, Haut ER, Kisat MT, Villegas CV, Chi A, et al. Outcome of selective non-operative management of penetrating abdominal injuries from the North American National Trauma Database. Br J Surg 2012;99:155-64. [CrossRef]

22. Peev MP, Chang Y, King DR, Yeh DD, Kaafarani H, Fagenholz PJ, et al. Delayed laparotomy after selective non-operative management of penetrating abdominal injuries. World J Surg 2015;39:380-6. [CrossRef]

23. Hope WW, Smith ST, Medieros B, Hughes KM, Kotwall CA, Clancy TV. Non-operative management in penetrating abdominal trauma: is it feasible at a Level II trauma center?.J Emerg Med 2012;43:190-5. [CrossRef] 


\section{ORİIINAL ÇALIŞMA - ÖZET}

\section{Sivil nedenli abdominal ateşli silah yaralanmalarında non-operatif tedavi}

\section{Dr. Adnan Özpek, Dr. Tolga Canbak}

Sağlık Bilimleri Üniversitesi, Ümraniye Eğitim ve Araştırma Hastanesi, Genel Cerrahi Kliniği, İstanbul

AMAÇ: Bu çalışmada sivil nedenli abdominal ateşli silah yaralanmalı (ASY) hastalarda selektif non-operatif tedavi (SNOT) sonuçlarını değerlendirmeyi amaçladık.

GEREÇ VE YÖNTEM: Kliniğimizde Ocak 2009 ile Ocak 2018 tarihleri arasında sivil nedenli abdominal ASY nedeniyle yatırarak takip ve tedavi ettiğimiz hastalar ileriye yönelik veri tabanında geriye dönük olarak incelendi. Hastalar yaş, cinsiyet, yaralanma şekli, anatomik yaralanma bölgesi, Yaralanma Şiddet Skoru (ISS), Revize Edilmiş Travma Skoru (RTS), Penetran Abdominal Travma İndeksi (PATI), uygulanan tedavi yöntemi, ameliyata alınma süresi, hastanede yatış gün sayısı ve mortalite yönünden irdelendi.

BULGULAR: Hastaların 84’ü (\%89.4) erkek, I0’u (\% I0.6) kadın, ortalama yaş 32.7 (4-60 yaş) idi. Seksen iki hasta (\%87.2) tabanca mermisi, I2 (\%।2.8) hasta tüfek saçması ile yaralanmıştı. Tüm hastaların ortalama ISS, RTS ve PATI değerleri sırasıyla I7.05, 7.27 ve 9.2। bulundu. Hastaların 2 I'ine (\%22.3) hemodinamik instabilite, 27'sine (\%28.7) ise peritonit bulguları nedeniyle hemen acil laparatomi ve/veya torakotomi uygulandı. Diğer 46 (\%48.9) hasta kliniğe yatırılarak takip edildi. Bu hastalardan peritonit bulguları gelişen 5'ine (\%5.3) erken laparatomi, 8'ine (\%8.5) geç laparatomi uygulandı. Geriye kalan 33 (\%35.I) hasta non-operatif olarak tedavi edildi. Flank yaralanmalarının \%6I.l'i, sağ torakoabdominal yaralanmaların \%50'si, posteriyor abdominal yaralanmaların \%44.4'ü, pelvik yaralanmaların \%42. I’i ve sol torakoabdominal yaralanmaların \%27.8'i başarılı şekilde SNOT uygulaması ile taburcu edildi. Sadece $6(\% 6.4)$ hastaya gereksiz laparatomi uygulandı, toplam 10 (\% I0.6) hastada mortalite gelişti.

TARTIŞMA: Hemodinamisi stabil olan ve peritonit bulgusu mevcut olmayan, belirli anatomik lokalizasyondaki sivil nedenli abdominal ASY'li hastaların bir kısmı, delici-kesici alet yaralanmalı hastalar gibi non-operatif tedavi edilebilir. Böylece gereksiz laparatomi ve buna bağlı komplikasyonlar azaltılabilir. Özellikle flank, posterior abdominal, torakoabdominal ve pelvik bölgenin ASY'de non-operatif takip ve tedavinin başarı oranlarının yüksek olduğu hatırda tutulmalıdır.

Anahtar sözcükler: Abdominal travma; ateşli silah yaralanması; seçici non-operatif takip; sivil yaralanma.

Ulus Travma Acil Cerrahi Derg 2020;26(2):227-234 doi: 10.14744/tjtes.2020.86। 32 